\title{
Меры аАминистративного пресечения, применяемые сотрудниками уголовно-исполительной системы Российской Федерации в связи с совершением аАминистративного правонарушения
}

\author{
С. А. СТАРОСТИН \\ Московский государственный юридический университет им. О. Е. Кутафина \\ (МГЮА), г. Москва, Российская Федерация \\ ORCID: https://orcid.org/ 0000-0002-0108-7916, e-mail: SASTAROSTIN@msal.ru
}

\author{
Н. В. АНИСКИНА \\ Вологодский институт права и экономики ФСИН России, г. Вологда, Россий- \\ ская Федерация
}

ORCID: https://orcid.org/0000-0002-7185-5730, e-mail: AniskinaN555@yandex.ru

\begin{abstract}
Р е фер ат
Введение: статья посвящена изучению теории и практики применения мер административного пресечения, реализуемых сотрудниками уголовно-исполнительной системы Российской Федерации в связи с совершением административного правонарушения. Обосновывается идея о влиянии эффективности применения сотрудниками уголовно-исполнительной системы мер административного принуждения не только на общий уровень пенитенциарной безопасности, но и на государственную безопасность в целом. Цель: установление особенностей применения мер административного пресечения в УИС с учетом специфики сферы правореализации. Методы: в основе проведенного исследования лежит диалектический метод научного познания. В статье использованы общенаучные (анализ, синтез, индукция и т. д.), частнонаучные и специальные методы познания (сравнительно-правовой, формально-юридический, статистический). Результаты: установлена сущность применения мер административного пресечения в УИС; изучена практика реализации норм, касающихся применения сотрудниками УИС мер административного пресечения; выявлены особенности их применения с учетом специфики сферы правореализации, такие как направленность на обеспечение пенитенциарной безопасности, предотвращение как административных правонарушений, так и преступлений, использование в большинстве случаев на территории учреждений УИС и др. Установлено, что правовая основа применения мер административного пресечения в уголовноисполнительной системе Российской Федерации нуждается в совершенствовании. Выводы: в целях повышения эффективности практики реализации мер административного принуждения в УИС сформулированы предложения по совершенствованию норм действующего законодательства, а именно обоснована необходимость закрепления в разд. V закона Российской Федерации от 21.07.1993 № 5473-1 определений терминов «применение физической силы» и «применение специальных средств», разграничения понятий применения и использования огнестрельного оружия, замены формулировки «оказание первой медицинской помощи» на «безотлагательное оказание пострадавшим первой доврачебной помощи». Также авторами приводятся аргументы в пользу целесообразности дополнения Федерального закона от 19.07.2018 № 197-ФЗ «О службе в уголовно-исполнительной системе Российской Федерации...» положением, закрепляющим за сотрудниками УИС обязанность по соблюдению норм уголовного законодательства (о необходимой обороне, крайней необходимости и иных обстоятельствах, исключающих преступность деяния) в случаях реализации мер административного пресечения.

Ключевы е слова: уголовно-исполнительная система; административное принуждение; Федеральная служба исполнения наказаний; сотрудник уголовно-исполнительной системы Российской Федерации; административное правонарушение; меры административного пресечения; пенитенциарная безопасность.
\end{abstract}

12.00.14 - Административное право; административный процесс. 
Для цитиров ания: Старостин С. А., Анискина Н. В. Меры административного пресечения, применяемые сотрудниками уголовно-исполнительной системы Российской Федерации в связи с совершением административного правонарушения. Пенитенциарная наука, 2021, т. 15, № 3 (55), c. 540-552. DOI 10.46741/26869764-2021-15-3-540-552.

\title{
Administrative Restraint Measures Applied by Employees of the Penal System of the Russian Federation in Connection with the Commission of an Administrative Offense
}

\author{
SERGEI A. STAROSTIN \\ Kutafin Moscow State Law University (MSLA), Moscow, Russian Federation \\ ORCID: https://orcid.org/0000-0002-0108-7916, e-mail: SASTAROSTIN@msal.ru
}

\section{NADEZHDA V. ANISKINA}

Vologda Institute of Law and Economics of FSIN Russia, Vologda, Russian Federation

ORCID: https://orcid.org/0000-0002-7185-5730, e-mail: AniskinaN555@yandex.ru

\begin{abstract}
Introduction: the article considers the theory and practice of applying administrative restraint measures implemented by employees of the penal system of the Russian Federation in case of the commission of an administrative offense. We substantiate an idea concerning the impact of the effectiveness of the use of administrative coercion measures by employees of the penal system not only on the overall level of penitentiary security, but also on state security in general. Aim: to reveal the specifics of application of administrative restraint measures in the penal system, taking into account the specifics of the law enforcement sphere. Methods: our research is based on the dialectical method of scientific cognition. The article uses general scientific (analysis, synthesis, induction, etc.), specific scientific and special methods of cognition (comparative legal, formal legal, statistical). Results: we reveal the essence of application of administrative restraint measures in the penal system; we study the practice of implementing the norms concerning the use of administrative restraint measures by employees of the penal system; we reveal the features of their application, taking into account the specifics of the sphere of law enforcement sphere, such as focusing on ensuring penitentiary security, preventing administrative offenses and crimes, application on the territory of penitentiary institutions in most cases, etc. We find out that the legal basis for the application of administrative restraint measures in the penal system of the Russian Federation needs to be improved. Conclusions: in order to increase the effectiveness of the practice of implementing administrative enforcement measures in the penal system, we formulate proposals to improve the norms of the current legislation: namely, Section $\mathrm{V}$ of the Law of the Russian Federation of July 21, 993 no. 5473-1 should contain definitions of the terms "use of physical force", "use of special means"; the terms such as application and use of firearms should be distinguished; the wording "provision of medical first aid" should be replaced with "immediate provision of premedical aid to victims". We also present arguments in favor of the expediency of supplementing Federal Law 197-FZ of July 19, 2018 "About the service in the Penal System of the Russian Federation..." with a provision that assigns to the employees of the penal system the duty to comply with the norms of criminal legislation (on necessary defense, extreme necessity and other circumstances excluding the criminality of the act) in cases of the implementation of administrative restraint measures.

Keywords: penal system; administrative coercion; Federal Penitentiary Service of Russia; employee of the penal system; administrative offense; administrative restraint measures; penitentiary security.
\end{abstract}

12.00.14 - Administrative law; administrative process. 
For citation: Starostin S.A., Aniskina N.V. Administrative restraint measures applied by employees of the penal system of the Russian Federation in connection with the commission of an administrative offense. Penitentiary Science, 2021, vol. 15, no. 3 (55), pp. 540-552. DOI 10.46741/2686-9764-2021-15-3-540-552.

\section{Введение}

В современных условиях функционирования Российской Федерации особую значимость приобретают вопросы, связанные с обеспечением национальной безопасности, заметную роль в обеспечении которой играют правоохранительные органы. Важное место в системе государственных органов, на которые возложена функция по обеспечению общественного порядка и общественной безопасности, в том числе на режимных объектах и территориях уголовно-исполнительной системы Российской Федерации, посредством применения мер административного принуждения, занимает Федеральная служба исполнения наказаний.

В системе мер административного принуждения значительным правоохранительным потенциалом обладают меры административного пресечения (административные меры защиты [5, с. 7]), поскольку именно они направлены на «прекращение (пресечение) совершаемого противоправного деяния или противоправного состояния» $[14$, с. 71$]$. Вместе с тем пресечение правонарушений, совершаемых в сфере исполнения уголовных наказаний, представляет собой важное направление деятельности ФСИН России, поскольку они несут в себе непосредственную угрозу не только установленному порядку функционирования учреждений, исполняющих наказания, и следственных изоляторов, но и государственной безопасности от пенитенциарной преступности в целом [30].

Как показали результаты поведенного нами исследования, повышенной общественной опасностью обладают правонарушения, связанные с передачей (попыткой передачи) запрещенных предметов лицам, содержащимся в учреждениях УИС [16]. Это связано с тем, что передаваемые запрещенные предметы могут выступать в качестве орудия совершения новых правонарушений (преступлений) не только на территории учреждений УИС, но и за ее пределами. В частности, по данным официальной статистики ФСИН России, в период с 2015 по 2020 г. наметилась определенная тенденция к росту (примерно на 20 \%) пенитенциарной преступности, в том числе в дистанционной форме, в то время как количество лиц, находящихся в местах лишения свободы в аналогичный период, сократилось на 21,83 \% (с 617,70 тыс. до 482,83 тыс. чел. [13]). Вместе с тем количество граждан, привлеченных к административной ответственности за передачу либо попытку передачи лицам, содержащимся в учреждениях УИС, запрещенных предметов, уменьшилось более чем на 60 \% (с 5009 в 2015 г. [20] до 1818 в 2020 г. [21]).

Представленные статистические данные свидетельствую о росте латентности совершаемых административных правонарушений по доставке запрещенных предметов на территорию учреждений УИС. При складывающихся обстоятельствах неэффективное применение мер административного пресечения в деятельности уполномоченных субъектов УИС может привести к несвоевременному выявлению и пресечению административных правонарушений, посягающих на установленный порядок управления в сфере функционирования учреждений УИС, и, как следствие, к совершению в дальнейшем новых правонарушений (преступлений). Указанные обстоятельства обусловливают актуальность темы исследования.

\section{Методы исследования}

В основе проведенного нами исследования лежит диалектический метод научного познания. В процессе написания статьи использовались общенаучные методы познания, частные методы общественных наук и специальные методы юридической науки.

Среди использованных в работе общенаучных методов можно выделить методы индукции и дедукции, метод системного анализа, синтеза и обобщения, метод сравнения и аналогии. Кроме того, для решения поставленных задач привлекались социологический и статистический общенаучные методы познания, а также частнонаучные методы в области юриспруденции: нормативно-логический, формально-юридический и сравнительно-правовой. Отдельные проблемы рассматривались как межотраслевые, что было обусловлено задачами комплексного анализа отношений в рамках 
заявленной темы. Кроме того, применялись приемы формальной логики и лексико-грамматического анализа, с помощью которых была осуществлена трактовка юридических понятий и терминов.

Неотъемлемой частью работы стал научный анализ статистических данных ФСИН России, Судебного департамента при Верховном Суде Российской Федерации, результатов собственного исследования.

\section{Обсуждение}

Применение мер административного пресечения ориентировано прежде всего на незамедлительное прекращение совершения противоправных действий в тот момент, когда «нарушение правопорядка еще длится или существует реальная угроза охраняемым законом общественным отношениям» [14, с. 74]. К мерам административного пресечения прибегают в том случае, если «все иные средства прекращения противоправных действий исчерпаны и нет других, которые способны обеспечить на должном уровне охрану правопорядка и безопасность граждан» [23, с. 74], что и объясняет их особый характер.

В большинстве своем применению мер административного пресечения предшествует отказ лица исполнять возложенные на него нормами действующего законодательства административно-правовые обязанности и запреты (например, запрет на нахождение посторонних лиц на режимных объектах УИС). В этой связи меры административного пресечения выступают своего рода ответной правоохранительной реакцией со стороны государства на противоправное, в том числе уголовно наказуемое, поведение лица, отказывающегося соблюдать те или иные правовые предписания [2].

Практическая реализация мер административного пресечения позволяет государству в лице уполномоченных органов и их должностных лиц оперативно реагировать на возникновение различного рода правовых аномалий с юридическим содержанием и тем самым поддерживать общественный порядок и общественную безопасность в различных сферах государственного управления.

Таким образом, меры административного пресечения представляют собой некую совокупность основных административно-правовых приемов, способов и средств воздействия на принуждаемый субъект, благодаря применению которых удается обеспечить прекращение административного и иного противоправного деяния непосредственно в момент его совершения, а также устранить реально существующие угрозы для личной или общественной безопасности.

Большинство исследователей в числе целей применения мер административного пресечения называют: прекращение (пресечение) неправомерных действий; ликвидацию противоправных состояний; предупреждение (предотвращение) наступления вредных последствий, появляющихся в результате возникновения чрезвычайных ситуаций социального, природного или техногенного характера; создание оптимальных условий для привлечения правонарушителей к ответственности [11; 18].

Вместе с тем основная цель применения данных мер административного принуждения в УИС напрямую вытекает из специфики деятельности ведомства - обеспечения пенитенциарной безопасности. В рамках исследования под пенитенциарной безопасностью мы будем подразумевать деятельность учреждений и органов УИС, сотрудников УИС и иных лиц, направленную на обеспечение жизненно важных интересов личности, общества и государства в сфере исполнения уголовных наказаний и защиту от потенциально и реально существующих угроз внешней и внутренней направленности.

Действительно, уровень пенитенциарной безопасности во многом зависит от действенности реализуемых уполномоченными субъектами УИС мер административного пресечения. Грамотное применение последних позволяет не допустить поступление на территорию учреждений УИС запрещенных предметов и вещей, прекратить (пресечь) совершение противоправных действий со стороны лиц, нарушающих установленный порядок управления в сфере исполнения уголовных наказаний, устранить иные объективно существующие угрозы для личной безопасности работников УИС и иных граждан, а также режимных объектов УИС.

Следует отметить, что в теории административного права разработано множество классификаций мер административного пресечения, однако большинство авторов придерживаются в своих работах точки зрения о подразделении мер административного пресечения на общие (обычные) и специальные (особые) [1, с. 32-44; 7, с. 7; 15, 
с. 56]. Данный подход мы возьмем за основу при характеристике мер пресечения в УИС.

Меры общего назначения в УИС по большей части урегулированы в Законе Российской Федерации от 21.07.1993 № 5473-1 «Об учреждениях и органах, исполняющих уголовные наказания в виде лишения свободы» (далее - Закон РФ № 5473-1) и Кодексе Российской Федерации об административных правонарушениях. Так, проведенный нами анализ законодательства и научной литературы по изучаемой проблематике позволяет выделить в качестве общих мер административного пресечения в деятельности УИС требование о прекращении совершения противоправных действий (правонарушений и преступлений), в том числе действий, препятствующих осуществлению законных полномочий сотрудников УИС, остановку транспортного средства и др. Не останавливаясь подробно на данной подгруппе мер административного пресечения, следует указать, что, по сути, они представляют собой обычную предусмотренную законом реакцию сотрудников УИС, которая позволяет пресечь противоправные действия на начальной стадии их совершения либо пока не наступили какие-либо неблагоприятные последствия для общественных отношений, складывающихся в сфере исполнения уголовных наказаний.

Наибольший интерес, на наш взгляд, представляет подгруппа специальных мер административного пресечения, к которой традиционно относят применение физической силы, специальных средств и огнестрельного оружия. В. Н. Опарин названные меры именует мерами непосредственного принуждения [19].

Правовую основу реализации специальных мер административного пресечения в УИС составляют нормы как международного, так и российского законодательства, в частности: Всеобщая декларация прав человека, Международный пакт об экономических, социальных и культурных правах, Конвенция о защите прав человека и основных свобод, Европейские пенитенциарные правила, Основные принципы применения силы и огнестрельного оружия должностными лицами по поддержанию правопорядка, Федеральный закон от 13.12.1996 № 150-ФЗ «Об оружии», Федеральный закон от 15.07.1995 № 103-Ф3 «О содержании под стражей подозреваемых и обвиняемых в совершении преступлений», Закон Российской Федера- ции от 21.07.1993 № 5473-1 «Об учреждениях и органах, исполняющих уголовные наказания в виде лишения свободы», приказ Минюста России от 30.10.2017 № 215 «Об утверждении Порядка ношения и применения огнестрельного оружия сотрудниками уголовно-исполнительной системы» и др.

Как справедливо отмечает А. В. Мингес, в качестве сущностной характеристики специальных мер пресечения выступает возможность их осуществления в форме физического воздействия на правонарушителя, что позволяет оказывать наиболее явное влияние на его личную неприкосновенность [17, с. 11]. Вследствие этого, вторгаясь в сферу прав и свобод конкретного лица, данные меры в большей степени наделены необходимым потенциалом по принуждению обязанных лиц к соблюдению установленных запретов и ограничений, исполнению обязанностей независимо от их воли и желания [29]. Фактически все меры административного пресечения объединяет общая черта: они несут в себе риск причинения вреда здоровью лица, к которому применяются.

Основания, условия и общий порядок применения физической силы, специальных средств и огнестрельного оружия в УИС регулируется гл. V Закона РФ № 5473-1. Детальное изучение данного закона позволяет прийти к выводу, что в нем не дается исчерпывающих характеристик используемых терминов, которые необходимы при оценке правомерности действий сотрудников УИС. В частности, отсутствует определение понятия «физическая сила», что предусматривает возможность усмотрения при использовании данного способа принудительного воздействия. Так, например, в процессе реализации специальной меры принуждения - физической силы - сотрудникам УИС приходится вступать в непосредственный физический, то есть телесный, контакт с объектом воздействия. В вязи с этим считаем, что под применением физической силы сотрудниками УИС следует понимать принудительное физическое (механическое) воздействие, включая боевые приемы борьбы, на правонарушителя, основанное на использовании мускульной силы и индивидуальных физических возможностей каждого конкретного сотрудника без использования специальных средств, оружия или иных подручных средств. Предлагаем данное определение закрепить в ст. 29 «Применение физической силы» Закона РФ № 5473-1. 
В контексте рассмотрения мер непосредственного принуждения нельзя не согласиться с О. О. Лебедевой, по мнению которой характер правоограничений и степень их воздействия на нарушителя должны зависеть от характера совершаемых противоправных действий (административного правонарушения или преступления), а также силы оказываемого им сопротивления (противодействия) [14, с. 93].

В том случае если применение физического воздействия к правонарушителю не привело к должному результату, сотрудники УИС дополняют его специальными средствами принуждения. В УИС предусмотрено применение следующих специальных средств принуждения: палок специальных, наручников и иных средств ограничения подвижности, служебных собак, специальных технических средств противодействия беспилотным воздушным судам и др. Также при необходимости сотрудники УИС в целях пресечения совершаемых правонарушений (преступлений) правомочны использовать «любые подручные средства» (ст. 28 Закона РФ № 5473-1).

На основании вышеизложенного представляется, что под применением специальных средств административного принуждения следует подразумевать воздействие сотрудников УИС на правонарушителя, реализуемое с помощью различных специальных технических устройств и приспособлений, состоящих на вооружении учреждений и органов УИС. Предлагаем данное определение закрепить в ст. 30 «Применение специальных средств» Закона РФ № 5473-1.

Самым опасным способом реализации мер административного пресечения, который в большей степени несет риски для жизни и здоровья правонарушителя, считается применение огнестрельного оружия. В связи этим данная мера в правоохранительной деятельности сотрудников УИС используется крайне редко, что подтверждается результатами проведенного нами анкетирования более 600 практических работников УИС: только 13 сотрудникам (2,16 \% от общего числа опрошенных) приходилось на практике применять огнестрельное оружие в отношении граждан (не осужденных).

Как отмечает А. М. Сильников, процесс применения огнестрельного оружия заключается в непосредственном использовании его «силы», то есть огнестрельных свойств самого оружия и поражающих свойств пули (снаряда) [25, с. 37-38]. Именно поэтому огнестрельное оружие в большинстве случаев применяют при возникновении объективной потребности в пресечении совершаемых преступлений, а не правонарушений.

Таким образом, перечень мер административного пресечения, реализуемых в практической деятельности сотрудников УИС, является весьма разнообразным, что позволяет их комбинировать между собой, исходя из необходимости достижения поставленной цели. Другими словами, практическая реализация данных мер может варьироваться от требования сотрудника УИС прекратить противоправное поведение до применения огнестрельного оружия.

Меры административного пресечения в УИС выступают одним из наиболее действенных способов борьбы с правонарушениями (преступлениями) в соответствующей сфере общественных отношений. Они носят универсальный характер, поскольку их применение позволяет пресечь совершение не только административных правонарушений, но и уголовных преступлений.

Представляется важным отметить, что в научной среде встречаются и иные взгляды относительно характера реализуемых специальных мер пресечения. Так, например, достаточно кардинальную позицию в отношении природы применения физической силы, специальных средств и оружия занимает С. Ю. Учитель. Он, в частности, предлагает приоритет в правовом регулировании специальных мер пресечения, реализуемых в правоприменительной деятельности правоохранительных органов, отдавать исключительно нормам уголовного права [27, C. 26].

Более компромиссный подход к вопросам правового регулирования и применения специальных мер пресечения представлен в работах В. А. Поникарова и С. В. Поникарова. Ученые считают, что применение огнестрельного оружия сотрудниками УИС возможно исключительно к лицам, совершившим уголовно наказуемое деяние, и относят его главным образом к мерам уголовно-правового характера, реализуемым при возникновении уголовно-правовых, а не административно-правовых отношений. В то же самое время они допускают вероятность применения физической силы и специальных средств для пресечения как административных правонарушений, так и уголовных преступлений [22, с. 119]. Ранее 
подобные взгляды получили отражение в работах В. Е. Северюгина [24].

На наш взгляд, отнесение огнестрельного оружия исключительно к мерам уголовного принуждения является не совсем оправданным и логичным, несмотря на то, что данная мера пресечения чаще всего применяется к лицам, которые совершают уголовно наказуемые деяния. Думается, что, исходя из специфики правового регулирования, особенностей реализации и субъектного состава, правоотношения, возникающие в связи с применением огнестрельного оружия, следует рассматривать исключительно как административные.

В. А. Мельников, беря за основу урегулированность рассматриваемой меры пресечения нормами административного права, также высказывается в поддержку отнесения огнестрельного оружия к мерам административного принуждения [15, с. 55]. При этом следует указать на универсальность реализуемых мер принудительного воздействия, которая предполагает возможность «обслуживания» мерами административного принуждения общественных отношений, урегулированных нормами иных отраслей права, даже при наличии несовпадения предмета регулирования и объекта охраны в том случае, если они не имеют собственных охранительных норм.

Вместе с тем проведенный нами детальный анализ положений Закона РФ № 5473-1 позволяет прийти к выводу, что в нем разграничивается два основных вида действий с огнестрельным оружием: применение и использование. Например, в п. 12 ст. 14 закреплено право учреждений, исполняющих уголовные наказания, на применение и использование в установленных законом случаях и порядке оружия и иных специальных мер пресечения. Данные термины по тексту закона и в российском законодательстве в целом используются как синонимы, что, на наш взгляд, является не совсем верным. На эту терминологическую особенность также обращали внимание Б. П. Кондрашов, Ю. П. Соловей и В. Б. Черников [12, с. 14].

Как совершенно справедливо отмечают А. И. Каплунов [9, с. 14] и Е. А. Алтухова [3, c. 43], такие действия с оружием, как применение и использование, следует различать в зависимости от объекта направленности принудительного воздействия. Так, понятие «применение огнестрельного оружия» подразумевает «применять на поражение, по живым объектам», понятие «использование огнестрельного оружия» не предполагает преднамеренное причинение вреда непосредственно жизни или здоровью человека даже при наличии такой возможности.

В Законе РФ № 5473-1 лишь в ст. 12 упоминается возможность использования и применения огнестрельного оружия в практической деятельности сотрудников УИС, далее по тесту говорится о возможности только его применения. Считаем, что для приведения положений рассматриваемого закона в соответствие с практикой реализации мер непосредственного принуждения уполномоченными субъектами УИС в ст. 31.2 необходимо внести изменения.

Во-первых, название статьи «Применение огнестрельного оружия» следует заменить на «Применение и использование огнестрельного оружия».

Во-вторых, в анализируемой статье необходимо закрепить возможность использования огнестрельного оружия сотрудниками УИС. Для этого в формулировке «Сотрудник уголовно-исполнительной системы также имеет право применять огнестрельное оружие» слово «применять» следует заменить на «использовать».

Сформулированный нами подход в части закрепления норм, устанавливающих порядок применения и использования огнестрельного оружия, мы могли встретить в ранее действовавшей редакции ст. 31 Закона РФ № 5473-1. Закрепление в данной норме термина «использовать» представляется необходимым в тех случаях, когда сотрудник УИС во время пресечения неправомерных действий направляет огнестрельное оружие не на живые объекты (людей), а на объекты материального мира (например, транспортные средства) либо пытается оказать воздействие на психику правонарушителя, осуществив производство предупредительного выстрела.

Сказанное позволяет прийти к выводу, что административным законодательством регламентируется порядок применения огнестрельного оружия, в то время как основанием для его применения может выступать не только административное правонарушение, но и уголовно наказуемое деяние. Вместе с тем, как показывает практика, использование огнестрельного оружия сотрудниками УИС в большинстве случаев имеет место для пресечения административных правонарушений, а применение - для пресечения 
совершения уголовных преступлений, например для защиты себя и (или) иных лиц от посягательства, если это посягательство сопряжено с насилием, опасным для жизни или здоровья (как вариант, в случае совершения преступления против жизни и здоровья, предусмотренного гл. 16 УК РФ).

В наибольшей степени отчетливо связь специальных мер административного пресечения с уголовно-правовыми нормами отражена в работах А. И. Каплунова [8, с. 254] и А. В. Мингеса [17, с. 19]. Данные ученые полагают, что прекращению причинения вреда правоохраняемым интересам может предшествовать необходимость применения регулируемых нормами административного и административно-процессуального права специальных мер пресечения. Вместе с тем данные меры могут быть конкретизированы, в частности, и нормами уголовного права, если в каком-либо конкретном случае при их применении будут задействованы уголовно-правовые институты: необходимой обороны; причинения вреда при задержании лица, совершившего преступление; крайней необходимости; физического или психического принуждения; обоснованного риска; исполнения приказа или распоряжения. Взаимосвязь норм административного и уголовного права в регулировании отношений по применению сотрудниками УИС физической силы, специальных средств и огнестрельного оружия отражена в ст. 28 Закона РФ № 5473-1.

Применение сотрудниками УИС мер административного пресечения возможно только с учетом установленного предела и правильного выбора средств. Правовое регулирование государством данного предела выступает важным условием (элементом) действующей системы административноправовых гарантий применения мер принуждения [4]. Именно поэтому считаем необходимым закрепить за сотрудниками УИС обязанность по соблюдению норм уголовного законодательства в процессе реализации административно-юрисдикционных полномочий по применению мер административного принуждения. В связи с этим предлагаем ст. 3 федерального закона «О службе в уголовно-исполнительной системе Российской Федерации» дополнить ч. 1.1 следующего содержания: «На деятельность сотрудника уголовно-исполнительной системы Российской Федерации распространяются нормы уголовного законодательства
Российской Федерации о необходимой обороне, крайней необходимости и иных обстоятельствах, исключающих преступность деяния».

В целях соблюдения законности в процессе реализации специальных мер административного пресечения сотрудники УИС обязаны соблюдать определенный порядок (последовательность) действий, регламентированный ст. 28.1 Закона РФ № 5473-1 и включающий три основных этапа.

Первый этап предусматривает обязанность сотрудника УИС предупредить правонарушителя о намерении применить специальную меру принуждения с предоставлением достаточного количества времени для выполнения своих требований. Форма данного предупреждения нормативно не установлена. Полагаем, что в качестве таковой могут выступать словесное (устное) предупреждение (предостережение о недопустимости противоправного поведения) либо предупредительный выстрел.

Второй этап предполагает совершение активных действий со стороны сотрудника УИС по применению конкретных мер пресечения - физической силы, специальных средств или огнестрельного оружия. Содержание указанных действий должно определяться «избранным способом принудительного воздействия» с учетом складывающейся обстановки [14, с. 139-140]. При этом они могут совершаться как независимо и изолированно друг от друга, так и в комплексе.

Выбор меры пресечения сотрудником УИС осуществляется с учетом сложившейся обстановки, характера и степени опасности противоправных действий лиц, а также силы оказываемого ими сопротивления [28]. Ключевым условием реализации исследуемых мер принуждения является закрепление за сотрудником УИС обязанности обеспечить наименьшее причинение вреда правонарушителю и предоставить ему в случае необходимости медицинскую помощь. Наименьшее причинение вреда правонарушителю реализуется за счет установления ограничений и запретов, связанных с применением специальных средств (ст. 31.1) и огнестрельного оружия (ст. 31.2).

В то же время необходимо отметить, что на практике сотрудник УИС, причинивший вред здоровью правонарушителя, может оказать ему только первую доврачебную, а не медицинскую помощь. Это связано с тем, 
что у сотрудников УИС, как правило, отсутствует специальное медицинское образование, а на курсах первоначальной подготовки они обучаются только навыкам оказания первой помощи пострадавшим. Обозначенное нами обстоятельство указывает на необходимость внесения в ст. 28.1 Закона РФ № 5473-1 корректив, а именно формулировку «безотлагательное предоставление пострадавшим медицинской помощи» следует заменить на «безотлагательное оказание пострадавшим первой доврачебной помощи». В рассматриваемом случае первая доврачебная помощь пострадавшим может включать остановку кровотечения, наложение повязки, проведение искусственного дыхания и др.

Помимо проблем, которые связаны с правовым регулированием института административного принуждения в уголовноисполнительной системе Российской Федерации, уполномоченные субъекты УИС зачастую сталкиваются с трудностями организационного характера в процессе его реализации. К примеру, на практике сотрудники УИС могут испытывать затруднения, связанные с вызовом медицинских работников для осуществления фиксации причиненных гражданам телесных повреждений. Это объясняется тем, что медицинский персонал учреждений УИС находится на рабочем месте, как правило, до обеда (14.00), а само учреждение может располагаться в удаленной от населенного пункта местности.

Последний (третий) этап заключается в обязательном доведении сотрудником УИС информации (докладе) непосредственному начальнику о каждом факте применения специальных мер административного принуждения в письменной форме в течение 24 часов. Как видим, принятие решения о применении специальных мер принуждения не предусматривает возбуждение индивидуального конкретного дела, законом устанавливается лишь обязательное требование к порядку фиксации каждого факта их применения с последующим уведомлением руководства.

Таким образом, в процессе реализации мер административного пресечения сотрудники УИС обязаны выполнять определенную последовательность (алгоритм) действий, что позволяет им не выходить за рамки правового поля, то есть соблюдать законность, и тем самым не нарушать права принуждаемых лиц.

\section{Результаты}

Меры административного пресечения в деятельности УИС осуществляются с учетом специфики сферы правореализации. Среди ключевых особенностей их применения представляется необходимым выделить следующие:

- административно-пресекательные меры в УИС применяются в целях обеспечения пенитенциарной безопасности, при этом внешняя форма принудительного воздействия на лицо может выражаться как в психическом (официальное требование о прекращении противоправных действий), так и в непосредственном воздействии на правонарушителя (применение физической силы, специальных средств и огнестрельного оружия);

- в качестве правовых оснований применения мер административного пресечения в УИС могут выступать: противоправное поведение лица, в том числе и объективно противоправное невиновное деяние; наступление особых состояний или событий, представляющих непосредственную угрозу для общественного порядка и общественной безопасности, а также безопасности объектов УИС и лиц, которые на них находятся. Для принятия сотрудником УИС решения о фактическом применении мер административного пресечения установление вины лица не требуется. Достаточно наличия материального основания, свидетельствующего о событии административного правонарушения, преступления или иной реально возникшей угрозы (наводнение, пожар и др.) для общественных отношений, складывающихся в сфере исполнения уголовных наказаний. На данное обстоятельство обращали свое внимание В. И. Кошевацкий [12, с. 103], Д. С. Дубровский [6, с. 24] и О. О. Лебедева [14, c. 75];

- применение мер административного пресечения не устанавливает обязанности уполномоченных субъектов определять состав правонарушения (преступления) в процессе их реализации. Кроме того, рядом исследователей было озвучено предложение о необходимости установления конкретного перечня административных правонарушений, совершение которых будет выступать в качестве основания для применения административных мер пресечения. Например, данной позиции придерживается В. А. Тюрин [26, с. 27]. Между тем справедливым и обоснованным нам видится подход А. П. Ко- 
ренева и А. И. Каплунова, которые в определении административного пресечения указывают не только на административную, но и на уголовную ответственность [8, с. 237]. Реализация мер административного принуждения может предшествовать использованию более строгих по своему характеру мер государственного принуждения;

- применение мер административного пресечения в УИС представляется возможным только в отношении «наличного или действительного противоправного деяния» [25, с. 27], то есть они обладают конкретной пространственно-временной характеристикой и применяются непосредственно в период совершения правонарушения;

- сотрудники УИС, как правило, применяют административно-пресекательные меры на территории учреждений УИС (исправительные учреждения и следственные изоляторы), а также на прилегающих к ним территориях, на которые распространяются режимные требования. В данном случае речь идет о необходимости соблюдения принципа территориальности в процессе реализации мер административного принуждения уполномоченными субъектами УИС. Вместе с тем действующее законодательство допускает реализацию админи- стративно-пресекательных мер за пределами территорий учреждений УИС, перечень данных территорий закреплен в ст. 28 Закона РФ № 5473-1;

- при применении мер пресечения сотрудники УИС обязаны руководствоваться нормативными положениями административного законодательства в части установления общих условий, оснований и порядка их применения, а также нормами уголовного законодательства об обстоятельствах, исключающих преступность деяния.

Таким образом, меры административного пресечения, реализуемые в административно-юрисдикционной деятельности уполномоченных субъектов УИС, отличаются определенным внутренним содержанием, которое предусматривает наличие конкретной цели, оснований и порядка их применения с учетом специфики функционирования пенитенциарной системы.

Сформулированные нами предложения по внесению изменений в нормы действующего законодательства будут способствовать повышению эффективности реализации мер административного пресечения в уголовно-исполнительной системе Российской Федерации.

\section{СПИСОК ЛИТЕРАТУРЫ}

1. Агеенкова, Г. Т. Проблемы совершенствования законодательства о мерах административного пресечения / Г. Т. Агеенкова // Актуальные проблемы советского административного и финансового права : сборник научных трудов / ответственный редактор П. Т. Василенков. - Москва : ВЮЗИ, 1984. - С. 32-44.

2. Административное право России. Общая часть : учебник / А. П. Алегин, Л. М. Колодкин, А. М. Колосков [и др.]. Москва : ООО «Науч. -издат. центр ИНФРА-М», 2010. - 506 с. - ISBN 978-5-16-004441-5.

3. Алтухова, Е. А. Некоторые вопросы правового регулирования осуществления сотрудниками УИС мер государственного принуждения / Е. А. Алтухова // Уголовно-исполнительное право. - 2014. - № 1 (17). - С. 42-45.

4. Анискина, Н. В. Соблюдение принципа территориальности при применении мер административного принуждения сотрудниками правоохранительных органов / Н. В. Анискина // Административное право и процесс. - 2020. № 1. - C. 72-76. - DOI 10.18572/2071-1166-2020-1-72-76.

5. Ардашкин, В. Д. Меры защиты (пресечения) в советском административном праве : автореферат диссертации на соискание ученой степени кандидата юридических наук / Ардашкин Владимир Дмитриевич. - Томск, 1968. - 17 с. 6. Дубровский, Д. С. Меры административного пресечения, ограничивающие свободу личности / Д. С. Дубровский. - Москва : Рос. акад. правосудия, 2009. - 150 с. - ISBN 978-5-93916-162-6.

7. Зеленько, В. Л. Вопросы теории и практики применения милицией мер административного пресечения правонарушений : автореферат диссертации на соискание ученой степени кандидата юридических наук / Зеленько Василий Леонидович. - Киев, 1975. - 17 с.

8. Каплунов, А. И. Административное принуждение, применяемое органами внутренних дел (системно-правовой анализ) : диссертация на соискание ученой степени доктора юридических наук / Каплунов Андрей Иванович. - Москва, 2005. - 498 с.

9. Каплунов, А. И. Правовые и тактические основы применения милицией огнестрельного оружия : автореферат диссертации на соискание ученой степени кандидата юридических наук / Каплунов Андрей Иванович. - Москва, 1994. - 24 c.

10. Ковшевацкий, В. И. К вопросу о сущности и правовой природе административного принуждения / В. И. Ковшевацкий // Вестник Московского университета МВД России. - 2015. - № 6. - С. 101-103.

11. Кокорев, А. Н. Меры административного пресечения, применяемые органами внутренних дел : диссертация на соискание ученой степени кандидата юридических наук / Кокорев Александр Николаевич. - Москва, 2007. - 253 с. 12. Кондрашов, Б. П. Внимание: оружие! (Правовые основы применения огнестрельного оружия сотрудниками российской милиции) / Б. П. Кондрашов, Ю. П. Соловей, В. В. Черников. - 2-е изд., испр. и доп. - Москва : Интердетектив, 1992. - 159 с. - ISBN 5-7175-0021-1. 
13. Краткая характеристика уголовно-исполнительной системы // Федеральная служба исполнения наказаний : официальный сайт. - URL: http://Фсин.рф/structure/inspector/iao/statistika/Kratkaya\%20har-ka\%20UIS/ (дата обращения: 30.04.2021).

14. Лебедева, О. О. Правовое регулирование применения принудительных мер административного предупреждения и пресечения : диссертация на соискание ученой степени кандидата юридических наук / Лебедева Оксана Олеговна. - Нижний Новгород, 2017. - 233 с.

15. Мельников, В. А. Проблемы определения принудительных мер административного пресечения / В. А. Мельников // Право и практика. - 2013. - № 2. - С. 52-60.

16. Мельникова, Н. А. Юридический состав передачи запрещенных предметов осужденным, содержащимся в учреждениях уголовно-исполнительной системы / Н. А. Мельникова, В. И. Воробьев // Актуальные вопросы административной деятельности органов государственной власти : сборник научных трудов. - Вологда : ВИПЭ ФСИН России, 2020. - С. 61-68.

17. Мингес, А. В. Реализация конституционного права на неприкосновенность личности в сфере специального административного пресечения : автореферат диссертации на соискание ученой степени кандидата юридических наук / Мингес Александр Викторович. - Свердловск, 1990. - 18 с.

18. Нагорных, Р. В. Административно-правовое принуждение / Р. В. Нагорных // Сущность, формы и методы реализации исполнительной власти : учебное пособие для магистратуры по направлению подготовки «Юрист в сфере государственного управления». - Вологда : ВИПЭ ФСИН России, 2019. - С. 133-155.

19. Опарин, В. Н. Правовое регулирование применения мер непосредственного принуждения должностными лицами правоохранительных органов Российской Федерации : диссертация на соискание ученой степени кандидата юридических наук / Опарин Виталий Николаевич. - Омск, 1998. - 225 с.

20. Основные показатели деятельности уголовно-исполнительной системы ФСИН России за 2015 год : информационно-аналитический сборник. - Тверь : ФКУ НИИИТ ФСИН России, 2016. - 402 с.

21. Основные показатели деятельности уголовно-исполнительной системы ФСИН России за 2020 год : информационно-аналитический сборник. - Тверь : ФКУ НИИИТ ФСИН России, 2021. - 386 с.

22. Поникаров, В. А. Соотношение административно-правового и уголовно-правового регулирования применения оружия сотрудниками УИС и другими работниками правоохранительных органов / В. А. Поникаров, С. В. Поникаров // Человек: преступление и наказание. - 2014. - № 1 (84). - С. 119-121.

23. Попов, Л. Л. Правовая основа административно-принудительных мер охраны общественного порядка / Л. Л. Попов // Правовые основы обеспечения общественного порядка : учебное пособие / В. В. Лазарев, Л. Л. Попов, Л. М. Розин. - Москва : Академия МВД СССР, 1987. - С. 69-75.

24. Севрюгин, В. Е. Проблемы административного права : учебное пособие / В. Е. Севрюгин. - Тюмень : Тюмен. высш. шк. МВД РФ ; Тюмен. гос. ун-т., 1994. - 208 с.

25. Сильников, А. М. Организационно-правовые основы применения сотрудниками полиции специальных средств принуждения : диссертация на соискание ученой степени кандидата юридических наук / Сильников Алексей Михайлович. - Санкт-Петербург, 2011. - 205 с.

26. Тюрин, В. А. Проблемы применения мер пресечения в административном праве России : диссертация на соискание ученой степени доктора юридических наук / Тюрин Виктор Анатольевич. - Москва, 2004. - $341 \mathrm{c}$.

27. Учитель, С. Ю. Необходимая оборона и ее роль в правоохранительной деятельности : автореферат диссертации на соискание ученой степени кандидата юридических наук / Учитель Сергей Юрьевич. - Москва, 2003. - 179 с. 28. Rhodes, L. Human Rights, Those Who Are Governed and the Legitimacy of Law Enforcement / Lynn Rhodes // Comparative Civilizations Review. - 2020. - Volume 82, no. 82. - P. 5.

29. Vuckovich, P. Justifying Coercion/PaulaK. Vuckovich, Barbara M. Artinian//Nursing Ethics. - 2005. - No. 12 (4). - Pp. 370 380. - DOI 10.1191/0969733005ne802oa. - URL: https://journals.sagepub.com/doi/abs/10.1191/0969733005ne802oa (дата обращения 21.05.2021).

30. Wooldredge, J. A macro-level perspective on prison inmate deviance / J. Wooldredge, B. Steiner // Punishment \& Society. - 2015. - 17 (2). - Pp. 230-257. - DOI 10.1177/1462474515577151. - URL: https://www.researchgate.net/ publication/275154681_A_macro-level_perspective_on_prison_inmate_deviance (дата обращения 21.05.2021).

\section{REFERENCES}

1. Ageenkova G.T. Problems of improving legislation on measures of administrative restraint. In: Vasilenkov P.T. (Ed.). Aktual'nye problemy sovetskogo administrativnogo i finansovogo prava : sbornik nauchnykh trudov [Topical issues of the Soviet administrative and financial law: a collection of scientific papers]. Moscow: VuZI, 1984. Pp. 32-44. (In Russ.). 2. Alegin A.P., Kolodkin L.M., Koloskov A.M. et al. Administrativnoe pravo Rossii. Obshchaya chast': uchebnik [Administrative law of Russia. General part: textbook]. Moscow: OOO "Nauch.-izdat. tsentr INFRA-M", 2010. 506 p.

3. Altukhova E.A. Some issues of legal regulation of the implementation of state coercion measures by employees of the penal system. Ugolovno-ispolnitel'noe pravo=Penal Law, 2014, no. 1 (17), pp. 42-45. (In Russ.).

4. Aniskina N.V. Complying with the principle of territoriality in the application of administrative coercive measures by law enforcement officers. Administrativnoe pravo i protsess=Administrative Law and Process, 2020, no. 1, pp. 72-76. DOI 10.18572/2071-1166-2020-1-72-76. (In Russ.).

5. Ardashkin V.D. Mery zashchity (presecheniya) v sovetskom administrativnom prave: avtoreferat dissertatsii na soiskanie uchenoi stepeni kandidata yuridicheskikh nauk [Measures of protection (restraint) in Soviet administrative law: Candidate of Sciences (Law) dissertation abstract]. Tomsk, 1968. 17 p.

6. Dubrovskii D.S. Mery administrativnogo presecheniya, ogranichivayushchie svobodu lichnosti [Measures of administrative restraint, which restrict the freedom of an individual]. Moscow: Ros. akad. pravosudiya, 2009. $150 \mathrm{p}$.

7. Zelen'ko V.L. Voprosy teorii i praktiki primeneniya militsiei mer administrativnogo presecheniya pravonarushenii: avtoreferat dissertatsii na soiskanie uchenoi stepeni kandidata yuridicheskikh nauk [Issues related to the theory and practice of the use of measures of administrative suppression of offenses by the police: Candidate of Sciences (Law) dissertation abstract]. Kyiv, 1975. 17 p.

8. Kaplunov A.I. Administrativnoe prinuzhdenie, primenyaemoe organami vnutrennikh del (sistemno-pravovoi analiz): dissertatsiya na soiskanie uchenoi stepeni doktora yuridicheskikh nauk [Administrative coercion applied by internal affairs bodies (system-legal analysis): Doctor of Sciences (Law) dissertation]. Moscow, 2005. 498 p. 
9. Kaplunov A.I. Pravovye i takticheskie osnovy primeneniya militsiei ognestrel'nogo oruzhiya: avtoreferat dissertatsii na soiskanie uchenoi stepeni kandidata yuridicheskikh nauk [Legal and tactical bases of the use of firearms by the police: Candidate of Sciences (Law) dissertation abstract]. Moscow, 1994. 24 p.

10. Kovshevatskii V.I. On the question of the essence and legal nature of administrative coercion. Vestnik Moskovskogo universiteta MVD Rossii=Bulletin of Moscow University of the Ministry of Internal Affairs of Russia, 2015, no. 6, pp. 101103. (In Russ.).

11. Kokorev A.N. Mery administrativnogo presecheniya, primenyaemye organami vnutrennikh del: dissertatsiya na soiskanie uchenoi stepeni kandidata yuridicheskikh nauk [Measures of administrative restraint applied by internal affairs bodies: Candidate of Sciences (Law) dissertation]. Moscow, 2007. 253 p.

12. Kondrashov B.P., Solovei Yu.P., Chernikov V.V. Vnimanie: oruzhie! (Pravovye osnovy primeneniya ognestrel'nogo oruzhiya sotrudnikami rossiiskoi militsii) [Attention: firearms! (Legal bases of the use of firearms by Russian police officers)]. Second edition, revised and supplemented. Moscow: Interdetektiv, 1992. 159 p.

13. Brief description of the penal system. Federal Penitentiary Service of Russia: official website. Available at: http://fsin.rf/ structure/inspector/iao/statistika/Kratkaya\%20har-ka\%20UIS/ (accessed April 30, 2021). (In Russ.).

14. Lebedeva O.O. Pravovoe regulirovanie primeneniya prinuditel'nykh mer administrativnogo preduprezhdeniya presecheniya: dissertatsiya na soiskanie uchenoi stepeni kandidata yuridicheskikh nauk [Legal regulation of the application of compulsory measures of administrative prevention and suppression: Candidate of Sciences (Law) dissertation]. Nizhny Novgorod, 2017. 233 p.

15. Mel'nikov V.A. Problems of determining compulsory measures of administrative restraint. Pravo i praktika=Law and Practice, 2013, no. 2, pp. 52-60. (In Russ.).

16. Mel'nikova N.A., Vorob'ev V.I. The legal composition of smuggling prohibited items to convicts held in institutions of the penal system. In: Aktual'nye voprosy administrativnoi deyatel'nosti organov gosudarstvennoi vlasti: sbornik nauchnykh trudov [Topical issues of administrative activity of state authorities: a collection of scientific papers]. Vologda: VIPE FSIN Rossii, 2020. Pp. 61-68. (In Russ.).

17. Minges A.V. Realizatsiya konstitutsionnogo prava na neprikosnovennost'lichnostivsfere spetsial'nogoadministrativnogo presecheniya: avtoreferat dissertatsii na soiskanie uchenoi stepeni kandidata yuridicheskikh nauk [Implementation of the constitutional right to personal inviolability in the field of special administrative restraint: Candidate of Sciences (Law) dissertation abstract]. Sverdlovsk, 1990. $18 \mathrm{p}$.

18. Nagornykh R.V. Administrative and legal coercion. In: Sushchnost', formy i metody realizatsii ispolnitel'noi vlasti: uchebnoe posobie dlya magistratury po napravleniyu podgotovki "Yurist v sfere gosudarstvennogo upravleniya" [The essence, forms and methods of implementing executive power: a textbook for master's degree courses in the field of training "Lawyer in the field of public administration"]. Vologda: VIPE FSIN Rossii, 2019. Pp. 133-155. (In Russ.).

19. Oparin V.N. Pravovoe regulirovanie primeneniya mer neposredstvennogo prinuzhdeniya dolzhnostnymi litsami pravookhranitel'nykh organov Rossiiskoi Federatsii: dissertatsiya na soiskanie uchenoi stepeni kandidata yuridicheskikh nauk [Legal regulation of the use of measures of direct coercion by law enforcement officials of the Russian Federation: Candidate of Sciences (Law) dissertation]. Omsk, 1998. 225 p.

20. Osnovnye pokazateli deyatel'nosti ugolovno-ispolnitel'noi sistemy FSIN Rossii za 2015 god: informatsionnoanaliticheskii sbornik [Main indicators of the activity of the penal system of the Federal Penitentiary Service of Russia for 2015: an information and analytical collection]. Tver: FKU NIIIT FSIN Rossii, 2016. 402 p.

21. Osnovnye pokazateli deyatel'nosti ugolovno-ispolnitel'noi sistemy FSIN Rossii za 2020 god: informatsionnoanaliticheskii sbornik [Main indicators of the activity of the penal system of the Federal Penitentiary Service of Russia for 2020: an information and analytical collection]. Tver: FKU NIIIT FSIN Rossii, 2021. $386 \mathrm{p}$

22. Ponikarov V.A., Ponikarov S.V. The ratio of administrative-legal and criminal-legal regulation of the use of firearms by employees of the penal system and other law enforcement officers. Chelovek: prestuplenie $i$ nakazanie=Man: Crime and Punishment, 2014, no. 1 (84), pp. 119-121. (In Russ.).

23. Popov L.L., Lazarev V.V., Rozin L.M. The legal basis of administrative and compulsory measures for the protection of public order. In: Pravovye osnovy obespecheniya obshchestvennogo poryadka: uchebnoe posobie [Legal bases for ensuring public order: a textbook]. Moscow: Akademiya MVD SSSR, 1987. Pp. 69-75. (In Russ.).

24. Sevryugin V.E. Problemy administrativnogo prava: uchebnoe posobie [Problems of administrative law: a textbook]. Tyumen: Tyumen. vyssh. shk. MVD RF: Tyumen. gos. un-t., 1994. 208 p.

25. Sil'nikov A.M. Organizatsionno-pravovye osnovy primeneniya sotrudnikami politsii spetsial'nykh sredstv prinuzhdeniya: dissertatsiya na soiskanie uchenoi stepeni kandidata yuridicheskikh nauk [Organizational and legal bases of the use of special means of coercion by police officers: Candidate of Sciences (Law) dissertation]. Saint Petersburg, 2011. 205 p.

26. Tyurin V.A. Problemy primeneniya mer presecheniya $v$ administrativnom prave Rossii: dissertatsiya na soiskanie uchenoi stepeni doktora yuridicheskikh nauk [Problems of the application of preventive measures in the administrative law of Russia: Doctor of Sciences (Law) dissertation]. Moscow, 2004. 341 p.

27. Uchitel' S.Yu. Neobkhodimaya oborona i ee rol' v pravookhranitel'noi deyatel'nosti: avtoreferat dissertatsii na soiskanie uchenoi stepeni kandidata yuridicheskikh nauk [Necessary defense and its role in law enforcement: Candidate of Sciences (Law) dissertation abstract]. Moscow, 2003. 179 p.

28. Rhodes L. Human rights, those who are governed and the legitimacy of law enforcement. Comparative Civilizations Review, 2020, vol. 82, no. 82, p. 5.

29. Vuckovich P.K., Artinian B.M. Justifying coercion. Nursing Ethics, 2005, no. 12 (4), pp. 370-380. DOI 10.1191/0969733005ne802oa. Available at: https://journals.sagepub.com/doi/abs/10.1191/0969733005ne802oa (accessed May 21, 2021).

30. Wooldredge J., Steiner B. A macro-level perspective on prison inmate deviance. Punishment \& Society, 2015, no. 17 (2), pp. 230-257. DOI: 10.1177/1462474515577151. Available at: https://www.researchgate.net/publication/275154681_A macro-level_perspective_on_prison_inmate_deviance (accessed May 21, 2021). 


\section{СВЕДЕНИЯ ОБ АВТОРАX / INFORMATION ABOUT THE AUTHORS}

СЕРГЕЙ АЛЕКСЕЕВИЧ СТАРОСТИН - ДОКТОР ЮрИдических наук, профессор, профессор кафедры административного права и процесса Московского государственного юридического университета им. О. Е. Кутафина (МГЮА), г. Москва, Российская Федерация, ORCID: https://orcid.org/0000-0002-01087916, e-mail: SASTAROSTIN@msal.ru

НАДЕЖДА ВЛАДИМИРОВНА АНИСКИНА - ПреПОдаватель кафедры административно-правовых дисциплин юридического факультета Вологодского института права и экономики ФСИН России, г. Вологда, Российская Федерация, ORCID: https://orcid.org/0000-0002 7185-5730,e-mail: AniskinaN555@yandex.ru
SERGEI A. STAROSTIN - Doctor of Sciences (Law), Professor, professor at the Department of Administrative Law and Process, Kutafin Moscow State Law University (MSLA), Moscow, Russian Federation, ORCID: https:// orcid.org/0000-0002-0108-7916,e-mail: SASTAROSTIN@ msal.ru

NADEZHDA V. ANISKINA - lecturer at the Department of Administrative and Legal Disciplines, Faculty of Law, Vologda Institute of Law and Economics of FSIN Russia, Vologda, Russian Federation, ORCID: https://orcid.org/0000-00027185-5730, e-mail: AniskinaN555@yandex.ru

Статья поступила 01.06.2021 